\title{
DROPLET DEPOSITION DURING SPRAY AND LEAF PH IN AQUATIC WEED CONTROL
}

\author{
Neumárcio Vilanova da Costa ${ }^{1 *}$; Dagoberto Martins ${ }^{1}$; Roberto Antonio Rodella²; Lívia Duarte \\ Neves de Camargo da Costa ${ }^{1}$ \\ ${ }^{1}$ UNESP/FCA - Depto. de Produção Vegetal (Agricultura), C.P. 237 - 18603-970 - Botucatu, SP - Brasil. \\ ${ }^{2}$ UNESP/IB - Depto. de Botânica, C.P. 510 - 18618-000 - Botucatu, SP - Brasil. \\ *Corresponding author <neumarcio@fca.unesp.br>
}

\begin{abstract}
The morphological diversity of leaf surface and structures such as trichomes, stomata, cuticle, and waxes that exists among plant species can have great influence on the adherence and deposition of spray droplets, as well as on herbicide absorption. The aim of this research was to study leaf $\mathrm{pH}$ and to evaluate wetting areas after applications of solution surfactants on the following aquatic weeds: Enhydra anagallis, Eichhornia crassipes, Heteranthera reniformis, and Typha subulata. The aquatic weeds were grown in reservoirs containing water under open air conditions and their leaf tissues were collected when the plants reached full development (before flowering). The mean leaf $\mathrm{pH}$ varied between 5.50 and 7.50; E. anagallis should be pointed out for presenting the highest $\mathrm{pH}$ values, of 6.68 and 7.02 on the upper and lower leaf surfaces, respectively. Surface tension reduction for glyphosate alone $\left(5.0 \% \mathrm{v} \mathrm{v}^{-1}\right)$, glyphosate + Aterbane BR $\left(5.0 \%+0.5 \% \mathrm{v} \mathrm{v}^{-1}\right)$, glyphosate + Silwet L-77 $\left(5.0 \%+0.05 \% \mathrm{v} \mathrm{v}^{-1}\right)$, and surfactants alone, Aterbane BR $\left(0.5 \% \mathrm{v} \mathrm{v}^{-1}\right)$, and Silwet L-77 $\left(0.05 \% \mathrm{v} \mathrm{v}^{-1}\right)$, were, respectively: $72.1 ; 28.7 ; 23.3 ; 37.3$, and $22.1 \mathrm{mN} \mathrm{m}^{-1} . T$. subulata was the aquatic species with the highest upper and lower leaf surface wetting area.

Key words: aquatic weed, glyphosate, surface tension, wetting
\end{abstract}

\section{DEPOSIÇÃO DE GOTAS DE PULVERIZAÇÃO E pH FOLIAR NO CONTROLE DE PLANTAS DANINHAS AQUÁTICAS}

\begin{abstract}
RESUMO: A diversidade morfológica da superfície foliar existente entre as espécies de plantas e a presença de estruturas foliares como tricomas, estômatos, cutícula e ceras podem exercer grande influência na aderência e deposição das gotas de pulverização, assim como na absorção do herbicida. Desta forma, o objetivo do presente trabalho foi estudar, em quatro espécies de plantas daninhas aquáticas (Enhydra anagallis, Eichhornia crassipes, Heteranthera reniformis e Typha subulata), a área de molhamento de gotas de pulverização nas superfícies foliares adaxial e abaxial, bem como o $\mathrm{pH}$ foliar. O experimento foi realizado em Botucatu-SP. As plantas foram cultivadas em caixas d'água sob condições de campo, e quando atingiram seu pleno desenvolvimento (antes do florescimento), foram realizadas as avaliações de $\mathrm{pH}$ foliar e da área de molhamento de gotas de pulverização. As tensões superficiais das gotas aplicadas $(0,5 \mu \mathrm{L})$, apresentadas pelas soluções de glyphosate aplicado isolado a $5,0 \% \mathrm{v} \mathrm{v}^{-1}$ (Rodeo $480 \mathrm{~g} \mathrm{~L}^{-1}$ e.a. - produto comercial), glyphosate + Aterbane BR $\left(5,0 \%+0,5 \% \mathrm{v} \mathrm{v}^{-1}\right)$, glyphosate + Silwet L-77 $\left(5,0 \%+0,05 \% \mathrm{v} \mathrm{v}^{-1}\right)$, além das soluções com os adjuvantes isolados, Aterbane BR $\left(0,5 \% \mathrm{v} \mathrm{v}^{-1}\right)$ e Silwet L-77 $\left(0,05 \% \mathrm{v} \mathrm{v}^{-1}\right)$ foram respectivamente 72,$1 ; 28,7 ; 23,3 ; 37,3$ e $22,1 \mathrm{mN} \mathrm{m}^{-1}$. As médias obtidas de $\mathrm{pH}$ foliar variaram entre 5,50 e 7,50, destacando-se a espécie E. anagallis com valores de 6,68 e 7,02 para as faces adaxial e abaxial, respectivamente. Dentre as plantas daninhas aquáticas avaliadas $T$. subulata foi a espécie que apresentou as maiores médias de área de molhamento nas faces adaxial e abaxial da folha, proporcionada pelas as soluções de glyphosate + Aterbane BR, glyphosate + Silwet L-77 e Silwet L-77, com valores de 12,99-7,03; 20,04-17,95 e 31,81-25,91 mm², respectivamente. Palavras-chave: planta aquática, glyphosate, tensão superficial, molhamento
\end{abstract}

\section{INTRODUCTION}

Aquatic plants are the main source of biomass production in aquatic ecosystems (Esteves, 1998). The excessive growth of these plants may cause a number of inconveniences related to waterway transportation, fishing, energy production, water supply, nautical sports, and proliferation of disease vectors, among others. From an environmental point of view, some fast-growing species may suppress other less aggressive species, desirable to maintain diversity, or may negatively modify some of the physical characteristics of water (Cardoso et al., 2002).

In a survey conducted in six reservoirs operated by Companhia Energética de São Paulo-CESP (Três Irmãos, Jupiá, Ilha Solteira, Porto Primavera, Paraibuna, and Jaguari, SP, Brazil), 29 aquatic plant species distributed through 17 families were identified; among these, the most frequent species in the reservoirs were 
Brachiaria subquadripara, Brachiaria mutica, Eichhornia crassipes, Typha spp., and Salvinia molesta, in addition to the submersed species Egeria densa, Egeria najas, and Ceratophyllum demersum (Tanaka et al., 2002; Carbonari et al., 2003). Some emersed aquatic species, Enhydra anagallis, Heteranthera reniformis, and Typha subulata, and floating aquatic species such as Eichhornia crassipes are already becoming a problem in hydroelectric and other types of reservoirs, due to their great reproductive capacity and biomass yield.

The efficacy of chemical control is related to several factors, among which are plant characteristics, pointed out as important variables; at present, this aspect has been poorly studied. The external morphology of the leaf surface of plants is highly variable, characterized by the presence of a protective coating, the epidermis and the cuticle; epicuticular waxes and trichomes may also be present. The topography of the leaf surface, the presence of wax, and trichomes may influence the distribution of a given herbicide applied on the leaf, and that the use of adjuvants may reduce the negative influence presented by these leaf structures (Hess \& Falk, 1990). The adjuvants used in sprays, known for the most part as surfactants or surface active agents, are substances that act on the interface forces of the spraying mix, whose aim is to provide a more effective droplet deposition and retention on the treatment target (Matuo et al., 1989).

The wettability of the leaf surface can be considered an important factor in the process of penetration of herbicides into the plant, and is essential to increase efficiency in weed control. To occur penetration through the cuticle, the sprayed droplet must be retained by the plant surface. The use of adjuvants in herbicide applications may increase the spreading, retention, and penetration of the active ingredient on the leaf surface, and reduce the rainfast period for the absorption of the product. The use of these additives can promote considerable economic and environmental benefits, because it is possible to reduce the recommended rate of active ingredients (Kirkwood, 1993).

The mechanism of action of surfactants is related to an effective increase in the contact area of the sprayed droplets with the leaf surface, dissolution or rupture of epicuticular waxes, prevention or delay in the formation of crystals in the sprayed droplet, and promotion of absorption of compounds via the stomata (Stock \& Holloway, 1993; Rodrigues \& Almeida, 1998). The surfactant Silwet L-77 may cause reductions in the surface tension of the spraying mix of approximately 19.5 to 22.9 $\mathrm{mN} \mathrm{m}{ }^{-1}$, ensuring excellent wettability of the adaxial surface of the leaf and allowing the mix to penetrate through the stomata (Buick et al., 1993).

The biological activity of pesticides applied on leaves is related to several factors associated with the physicochemical interaction between the toxic formula- tion and the plant surface. Thus, an important aspect of this interaction, which is mainly determinative of the initial character and subsequent availability of the deposit, is the behavior of the spray droplet, such as its impact and accumulation on leaf surface before penetration or evaporation of the liquid (Johnstone, 1973).

Knowledge about the target plant and the application mix is essential for the success of agricultural sprays, especially when herbicides are used (Mendonça, 2000). In addition to influences that are intrinsic to the plants, such as leaf arrangement, leaf $\mathrm{pH}$, epicuticular waxes, stomata, trichomes, and others, there are also extrinsic influences, such as the physicochemical characteristics of the spray solution, with emphasis on surface tension, wetting area, $\mathrm{pH}$ of the solution, and type of formulation; therefore, studies regarding these factors must be intensified. Knowing the botanical characteristics of aquatic weed species is highly useful, especially when it comes to telling species apart. However, morphological studies, particularly those dealing with leaf anatomy of aquatic plants and those correlated with spray droplet deposition, are very scarce in Brazil.

Thus, the objective of this work was to study the $\mathrm{pH}$ and wetting area of spray droplets on the adaxial (upper) and abaxial (lower) surfaces of leaf blades of four aquatic weed species, using solutions of different surface tension.

\section{MATERIAL AND METHODS}

Aquatic weeds were used in the experiment installed on March, 2002, in Botucatu, SP, Brazil: Enhydra anagallis, Eichhornia crassipes, Heteranthera reniformis, and Typha subulata, obtained and reproduced by means of their vegetative dispersion structures, and accommodated in full sun using 320-liter fiberglass reservoirs, containing a $15 \mathrm{~cm}$ soil layer at the bottom. Plants were submitted to a development period of four months. The chemical analysis of the soil resulted in a $\mathrm{pH}$ value of 5 in $\mathrm{CaCl}_{2}$, an organic matter content of $16 \mathrm{~g} \mathrm{dm}^{-3}, \mathrm{CEC}$ of 75 and a $\mathrm{P}$ content of $70 \mathrm{mg} \mathrm{dm}^{-3}$, and values of $1.9-28$ and $9 \mathrm{mmol}_{\mathrm{c}} \mathrm{dm}^{-3}$ for $\mathrm{K}, \mathrm{Ca}$, and $\mathrm{Mg}$, respectively, and $39 \%$ base saturation.

Plants were evaluated at full development (before flowering); leaves were sampled from pre-established plant parts for each species, according to their different habits. For Heteranthera reniformis and Enhydra anagallis, the third completely developed leaf was collected, counted from the first leaf developed from the tip of the branch toward the base. For Eichhornia crassipes, the leaf nearest the center of the rosette was collected. For Typha subulata, the third completely developed leaf was collected, counted from the first leaf showing a sheath from the center of the rosette toward the outer edge. 
Leaf $\mathrm{pH}$ was determined on the adaxial and abaxial surfaces of the leaves of each species, using a pHmeter (Corning brand, Model $314 \mathrm{pH} /$ Temperature Plus) connected to a microelectrode (Digimed brand, Model DME-CV7). A $35 \mu \mathrm{L}$ droplet of distilled water was placed between the leaf surface and the microelectrode. Distilled water $\mathrm{pH}$ was determined at the beginning of each reading, that is, every reading started at the distilled water $\mathrm{pH}$, and readings were taken every ten seconds; the final result was considered at the time when the equipment indicated a constant $\mathrm{pH}$ value reading. Eight replicates or determinations were made for each aquatic weed species.

The herbicide glyphosate $\left(5.0 \% \mathrm{v} \mathrm{v}^{-1}\right.$ of the commercial product Rodeo $480 \mathrm{~g} \mathrm{~L}^{-1}$ a.e.) without and with the addition of surfactants Aterbane BR and Silwet L-77, at commercial product concentrations of $0.5 \% \mathrm{v} \mathrm{v}^{-1}$ and $0.05 \% \mathrm{v} \mathrm{v}^{-1}$, respectively, was used to prepare solutions of different surface tensions. An application volume of $200 \mathrm{~L} \mathrm{ha}^{-1}$ was considered to provide a real-life condition.

The surface tension of each solution used to calculate spray droplet wetting area was determined according to the method proposed by Corrêa \& Velini (2002). The surface tension values used were: $72.6 \mathrm{mN} \mathrm{m}^{-1}$, corresponding to the surface tension of distilled water (control); $72.1 \mathrm{mN} \mathrm{m}^{-1}$, for the glyphosate solution applied individually; $28.7 \mathrm{mN} \mathrm{m}^{-1}$ for glyphosate + Aterbane BR; $23.3 \mathrm{mN} \mathrm{m}^{-1}$ for glyphosate + Silwet L-77; $37.3 \mathrm{mN} \mathrm{m}^{-1}$ for the solution containing surfactant Aterbane BR applied individually, and $22.1 \mathrm{mN} \mathrm{m}^{-1}$ for the solution containing surfactant Silwet L-77 applied individually.

The spray droplet wetting areas were determined on the adaxial and abaxial surfaces of the leaf blade in separate leaves for each species under study, with eight replicates. In each wetting area determination, the aquatic plant leaves were attached with a piece of double-sided adhesive tape onto the optical field of a photostereomicroscope, and a $0.5 \mu \mathrm{L}$ droplet of solution from the treatments was placed on the leaf surface, with a micropipette and were immediately photographed.

Brilliant blue dye $\left(0.4 \% \mathrm{v} \mathrm{v}^{-1}\right)$ was used in order to allow a better visualization of the wetting area, and a preliminary study was carried out to determine the dye concentration at which no interference would occur in the surface tension of distilled water (Figure 1). Wetting area measurements were made with a digitizing tablet interfaced with a computer equipped with Planimetry System software (SPLAN), developed by CINAG - UNESP/ Botucatu-SP.

A completely randomized design was used with leaf $\mathrm{pH}$ data for the adaxial and abaxial leaf surfaces, while a $2 \times 6$ factorial design was used with data on spray droplet wetting area for the leaf adaxial and abaxial surfaces (two surfaces $\times$ six surface tensions). All data were

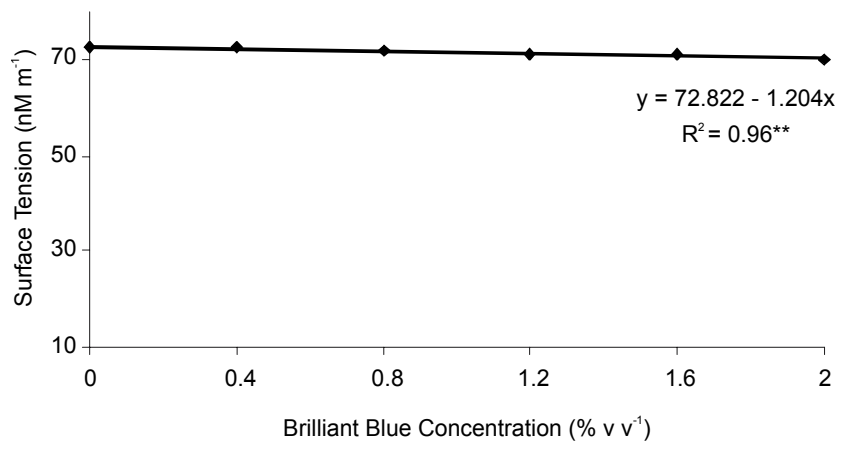

Figure 1 - Surface tension for the Brilliant blue dye.

statistically analyzed using " $\mathrm{t}$ " test $(P<0.05)$, and the minimum and maximum confidence intervals were determined (Pimentel-Gomes, 1976).

\section{RESULTS AND DISCUSSION}

Table 1 presents leaf $\mathrm{pH}$, minimum and maximum confidence intervals, and $\mathrm{F}_{\text {surfaces }}$, l.s.d., and $\mathrm{CV} \%$ values. Leaf $\mathrm{pH}$ of the adaxial and abaxial surfaces were similar for the four species studied.

Leaf $\mathrm{pH}$ varied between 5.50 and 7.50; Enhydra anagallis was prominent, showing the highest means, with values around 6.68 and 7.02 for the adaxial and abaxial surfaces, respectively. All species had abaxial surface means slightly higher than the means for the adaxial leaf surface, except Heteranthera reniformis, which were identical on both surfaces (5.63). Mendonça (2000) evaluated leaf $\mathrm{pH}$ in terrestrial weeds and observed variations ranging from 4.0 to 6.0 for the adaxial leaf surface of the species Commelina benghalensis presenting the highest value (6.0) and the species Cenchrus echinatus the lowest (4.4).

There is little information in the literature regarding the influence of leaf surface $\mathrm{pH}$ on the herbicide absorption process. Glyphosate becomes progressively less capable of passing through cell membranes as $\mathrm{pH}$ increases, so that at $\mathrm{pH} 5$ about 79.36 and $20.64 \%$ of the glyphosate molecules are in the form of mono and divalent anions, respectively, while at $\mathrm{pH} 8$ about 0.38 and $99.62 \%$ of the molecules are in the form of mono and divalent anions, respectively (Velini \& Trindade, 1992); thus, as $\mathrm{pH}$ increases from 5 to 8 , glyphosate becomes more ionized and hydrophilic. The absorption of lipophilic compounds occurs in a more effective and rapid way than that of hydrophilic compounds. Therefore, this behavior could indicate that species with high leaf surface $\mathrm{pH}$ may experience absorption difficulties during the process of absorption of glyphosate by the leaf through the lipophilic pathway, due to changes in the physicochemical characteristics of the product.

The means for the wetting area provided by a 0.5 $\mu \mathrm{L}$ droplet of solutions with different surface tensions on 
the adaxial and abaxial surfaces of leaves from different aquatic weed species are presented in Table 2. The droplet surface tensions shown by solutions of glyphosate individually $\left(5.0 \% \mathrm{v} \mathrm{v}^{-1}\right)$, glyphosate + Aterbane BR $(5.0 \%$ $\left.+0.5 \% \mathrm{v} \mathrm{v}^{-1}\right)$, glyphosate + Silwet L-77 (5.0\% + 0.05\% $\left.\mathrm{V} \mathrm{v}^{-1}\right)$, in addition to solutions containing the Aterbane BR $\left(0.5 \% \mathrm{v} \mathrm{v}^{-1}\right)$ and Silwet L-77 $\left(0.05 \% \mathrm{v} \mathrm{v}^{-1}\right)$ adjuvants individually were, respectively, 72.1 - 28.7 - 23.3 - 37.3, and $22.1 \mathrm{mN} \mathrm{m}^{-1} 0.5 \mu \mathrm{L}^{-1}$. These data are similar to those obtained by Costa (1997) for the same products and concentrations. The data obtained for spray droplet surface tension in glyphosate solutions mixed with adjuvants Aterbane BR and Silwet L-77 were below the surface tension cited by Greene \& Bucovac (1974), which would induce the solutions to penetrate via the stomata $\left(32 \mathrm{mN} \mathrm{m}^{-1}\right)$.

Table 1 - Leaf $\mathrm{pH}$ of the adaxial and abaxial surfaces of different aquatic weed species, with corresponding means, minimum and maximum confidence intervals, and $\mathrm{F}_{\text {surfaces }}$, l.s.d., and $\mathrm{CV} \%$ values.

\begin{tabular}{|c|c|c|c|c|c|c|}
\hline Species & Means & Min CI & Max CI & $\mathrm{F}_{\text {surfaces }}$ & 1.s.d. & $\mathrm{CV} \%$ \\
\hline \multicolumn{7}{|l|}{ Enhydra anagallis } \\
\hline Adaxial surface & $6.68 \mathrm{a}$ & 6.36 & 7.00 & $2.59^{\mathrm{ns}}$ & 0.45 & 6.12 \\
\hline Abaxial surface & $7.02 \mathrm{a}$ & 6.70 & 7.34 & & & \\
\hline \multicolumn{7}{|c|}{ Eichhornia crassipes } \\
\hline Adaxial surface & $5.77 \mathrm{a}$ & 5.53 & 6.00 & $1.93^{\text {ns }}$ & 0.33 & 5.29 \\
\hline Abaxial surface & $5.98 \mathrm{a}$ & 5.75 & 6.22 & & & \\
\hline \multicolumn{7}{|l|}{ Heteranthera } \\
\hline Adaxial surface & $5.63 \mathrm{a}$ & 5.34 & 5.93 & $0.00^{\mathrm{ns}}$ & 0.41 & 6.85 \\
\hline Adaxial surface & $5.63 \mathrm{a}$ & 5.34 & 5.93 & & & \\
\hline \multicolumn{7}{|l|}{ Typha subulata } \\
\hline Adaxial surface & $5.75 \mathrm{a}$ & 5.44 & 6.07 & $0.02^{\text {ns }}$ & 0.44 & 7.18 \\
\hline Abaxial surface & $5.78 \mathrm{a}$ & 5.47 & 6.10 & & & \\
\hline
\end{tabular}

Means followed by a common letter in the column do not differ by t test $(P<0.05)$.

${ }^{\mathrm{n}}$ non significant.

Table 2 - Wetting areas $\left(\mathrm{mm}^{2}\right)$ provided by a $0.5 \mu \mathrm{L}$ droplet of solutions with different surface tensions on the adaxial and abaxial surfaces of leaves from different aquatic weed species.

\begin{tabular}{|c|c|c|c|c|c|c|}
\hline \multirow{3}{*}{ Species } & \multicolumn{6}{|c|}{ Droplet surface tension $\left(\mathrm{mN} \mathrm{m}^{-1}\right)$} \\
\hline & 72.6 & 72.1 & 37.3 & 28.7 & 22.1 & 23.3 \\
\hline & $\begin{array}{l}\text { Distilled } \\
\text { water }\end{array}$ & glyphosate & Aterbane BR & $\begin{array}{l}\text { glyphosate }+ \\
\text { Aterbane BR }\end{array}$ & Silwet L-77 & $\begin{array}{l}\text { glyphosate }+ \\
\text { Silwet L-77 }\end{array}$ \\
\hline \multicolumn{7}{|l|}{ Enhydra anagallis } \\
\hline Adaxial surface & $2.14 \mathrm{aD}$ & $2.47 \mathrm{aCD}$ & $2.79 \mathrm{aCD}$ & $3.16 \mathrm{aC}$ & $11.04 \mathrm{aA}$ & $4.32 \mathrm{aB}$ \\
\hline Abaxial surface & $1.89 \mathrm{aD}$ & $2.07 \mathrm{aCD}$ & $2.85 \mathrm{aC}$ & $2.83 \mathrm{aCD}$ & $10.21 \mathrm{aA}$ & $4.46 \mathrm{aB}$ \\
\hline Means & 2.02 & 2.27 & 2.82 & 3.00 & 10.62 & 4.39 \\
\hline \multicolumn{7}{|c|}{ Eichhornia crassipes } \\
\hline Adaxial surface & $1.35 \mathrm{aD}$ & $1.90 \mathrm{aCD}$ & $2.82 \mathrm{bC}$ & $2.70 \mathrm{aC}$ & $6.52 \mathrm{aA}$ & $4.19 \mathrm{aB}$ \\
\hline Abaxial surface & $2.09 \mathrm{aD}$ & $1.96 \mathrm{aD}$ & $4.09 \mathrm{aBC}$ & $3.52 \mathrm{aC}$ & $7.04 \mathrm{aA}$ & $4.91 \mathrm{aB}$ \\
\hline Means & 1.72 & 1.93 & 3.45 & 3.11 & 6.78 & 4.55 \\
\hline \multicolumn{7}{|c|}{ Heteranthera reniformis } \\
\hline Adaxial surface & $1.58 \mathrm{bD}$ & $1.73 \mathrm{bD}$ & $2.43 \mathrm{bC}$ & $2.82 \mathrm{bC}$ & $5.88 \mathrm{aA}$ & $4.41 \mathrm{aB}$ \\
\hline Abaxial surface & $2.48 \mathrm{aC}$ & $2.44 \mathrm{aC}$ & $3.02 \mathrm{aB}$ & $3.39 \mathrm{aB}$ & $4.42 \mathrm{bA}$ & $3.19 \mathrm{bB}$ \\
\hline Means & 2.03 & 2.08 & 2.73 & 3.11 & 5.15 & 3.80 \\
\hline \multicolumn{7}{|l|}{ Typha subulata } \\
\hline Adaxial surface & $0.87 \mathrm{aE}$ & $1.57 \mathrm{aDE}$ & $4.34 \mathrm{aD}$ & $12.99 \mathrm{aC}$ & $31.81 \mathrm{aA}$ & $20.04 \mathrm{aB}$ \\
\hline Abaxial surface & $0.97 \mathrm{aD}$ & $1.09 \mathrm{aD}$ & $6.36 \mathrm{aC}$ & $7.03 \mathrm{bC}$ & $25.91 \mathrm{bA}$ & $17.95 \mathrm{aB}$ \\
\hline Means & 0.92 & 1.33 & 5.35 & 10.01 & 28.86 & 18.99 \\
\hline
\end{tabular}

Means followed by a common lower case letter in the column, and a common upper case letter in the row, do not differ by t Test $(P<0.05)$. 
The surface tension for adjuvants Aterbane BR $\left(0.5 \% \mathrm{v} \mathrm{v}^{-1}\right)$ and Silwet L-77 $\left(0.05 \% \mathrm{v} \mathrm{v}^{-1}\right)$ in distilled water were higher than the tension found by Mendonça (2000), who worked with lower concentrations of the adjuvants Aterbane BR $\left(0.03 \% \mathrm{v} \mathrm{v} \mathrm{v}^{-1}\right)$ and Silwet L-77 $\left(0.02 \% \mathrm{v} \mathrm{v}^{-1}\right)$ and obtained surface tension values in the order of 33.8 and $20.8 \mathrm{~m} \mathrm{~N} \mathrm{~m}^{-1}$, respectively. Montório (2001) verified that the adjuvants Aterbane BR and Silwet L-77 presented reductions in water surface tension and an efficacy coefficient around $32.68-19.08 \mathrm{mN} \mathrm{m}^{-1}$ and 46.38 - 143.43, respectively.

For the species Enhydra anagallis, the mean wetting areas provided by droplets of glyphosate, Aterbane BR, and glyphosate + Aterbane BR solutions were similar, considering the solutions within each leaf surface (adaxial or abaxial). Therefore, Aterbane BR was ineffective in spreading the spray droplet on the leaf surface of this species. Likewise, there were no significant differences for surface within each solution, for all evaluated treatments. However, the glyphosate + Silwet L-77 and Silwet L-77 solutions had the largest wetting areas in relation to the other treatments, of $4.32-4.46$ and $11.04-10.21 \mathrm{~mm}^{2} 0.5 \mu \mathrm{L}^{-1}$ on the adaxial and abaxial leaf surfaces, respectively (Table 2 and Figure 2).
Figure 3 presents spray droplet wetting area results for the adaxial and abaxial surfaces of the aquatic weed Eichhornia crassipes. Higher leaf wetting area means can be observed for the abaxial surface in comparison with the adaxial surface, and only the Aterbane BR solution presented differences between surfaces (Table 2). There were differences for solution within each leaf surface. The Silwet L-77 solution applied individually provided the largest wetting area on the adaxial and abaxial surfaces, with means of 6.52 and $7.04 \mathrm{~mm}^{2} 0.5$ $\mu \mathrm{L}^{-1}$, respectively.

Martins et al. (1999) evaluated the effect of glyphosate $\left(3,360 \mathrm{~g}\right.$ a.e. $\left.\mathrm{ha}^{-1}\right)$ without adjuvant in the control of Eichhornia crassipes under controlled conditions and obtained control means higher than $90 \%$ at 35 days after application. However, Cardoso et al. (2003) evaluated chemical control in six Eichhornia crassipes accessions collected from reservoirs in the State of São Paulo, using the herbicide glyphosate at rates of 1,680 and 3,360 g a.e. ha ${ }^{-1}+0.5 \% \mathrm{v} \mathrm{v}^{-1}$ of the adjuvant Extravon, and obtained control ratings varying between 91 and $100 \%$ at 14 days after application. When adjuvants are added to the spray mix, the appearance of phytotoxic effects from glyphosate can be accelerated, providing faster and more effective control against weed species.

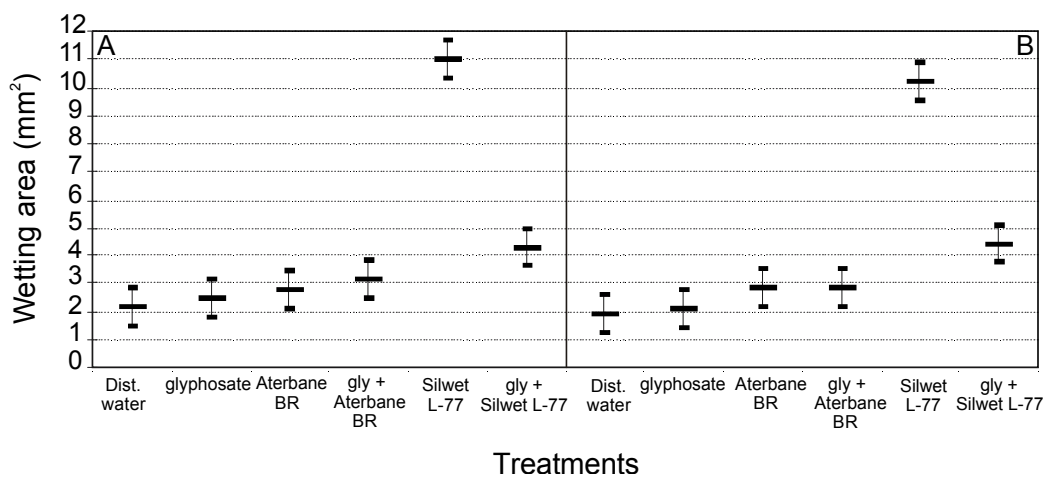

Figure 2 - Wetting area for different solutions provided by a $0.5 \mu \mathrm{L}$ droplet deposited on the adaxial (A) and abaxial (B) surfaces of Enhydra anagallis leaves (minimum and maximum confidence intervals).

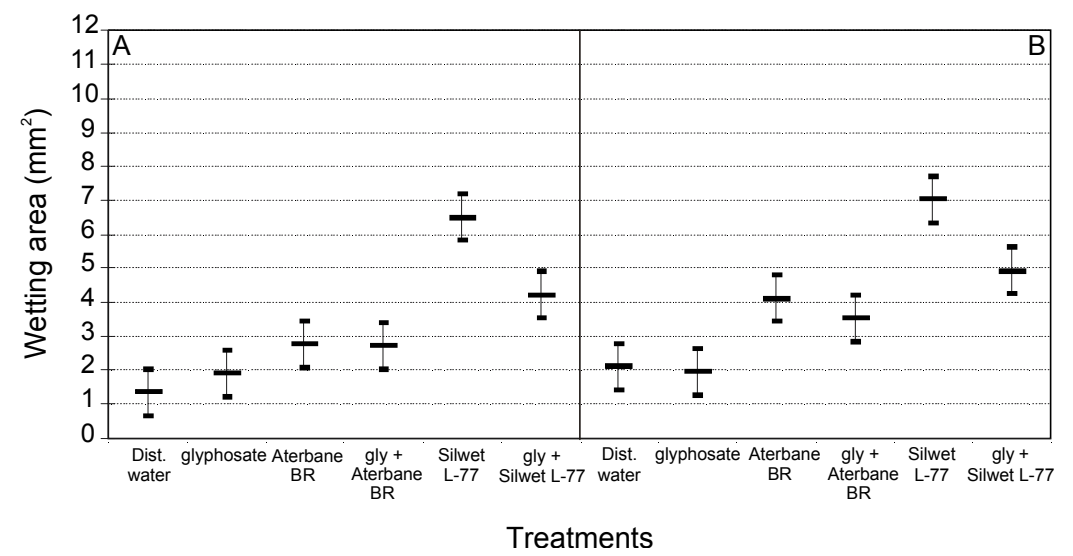

Figure 3 - Wetting area for different solutions provided by a $0.5 \mu \mathrm{L}$ droplet deposited on the adaxial (A) and abaxial (B) surfaces of Eichhornia crassipes leaves (minimum and maximum confidence intervals). 
For the aquatic weed Heteranthera reniformis, the droplets of distilled water, glyphosate, Aterbane BR, and glyphosate + Aterbane BR solutions presented the highest wetting area means of the abaxial surface, while the opposite was observed for Silwet L-77 and glyphosate + Silwet L-77 solutions (Figure 4). All treatments differed for surface within each solution and for solution within each surface, with emphasis on the glyphosate + Aterbane BR, glyphosate + Silwet L-77, and Silwet L-77 solutions, which presented the highest means for both surfaces (Table 2). Among the aquatic weeds evaluated, Typha subulata was the species that obtained the highest wetting area means on the adaxial and abaxial leaf surfaces, provided by the glyphosate + Aterbane BR, Silwet L-77, and glyphosate + Silwet L-77 solutions. Only the glyphosate + Aterbane BR and Silwet L-77 solutions presented differences for surfaces within solutions. Silwet L77 and glyphosate + Silwet L-77 obtained means ranging from $31.81-25.91$ and $20.04-17.95 \mathrm{~mm}^{2} 0.5 \mu \mathrm{L}^{-1}$ for wetting area on the adaxial and abaxial leaf surfaces, respectively (Table 2 and Figure 5). Silva (2003) evaluated the effects of glyphosate $\left(4.5 \% \mathrm{~V} \mathrm{v}^{-1}\right)$ mixed with the adjuvants Aterbane BR $\left(0.5 \% \mathrm{v} \mathrm{v}^{-1}\right)$ or Silwet L-77 $\left(0.01 \% \mathrm{~V} \mathrm{v}^{-1}\right)$ for the control of Typha subulata and did not observe differences between treatments, which pre- sented control means of $100 \%$ at 80 days after application. However, the author mentioned that, although the addition of adjuvants uniformized the distribution of glyphosate on the plant, the mean deposition per $\mathrm{cm}^{2}$ of leaf area was higher for the treatment without adjuvants. Adjuvants may have caused greater mix runoff on the leaves, justifying the lower mean deposition values of applied mix per $\mathrm{cm}^{2}$ of leaf area.

Hess \& Falk (1990) and Mendonça (2000) explained that greater epicuticular wax deposits on the adaxial surface of the leaf may reduce spreading of the spray droplet on such a surface. Mendonça (2000) observed larger wetting areas on the abaxial leaf surfaces of the grasses Brachiaria decumbens, Brachiaria plantaginea, and Panicum maximum, obtained for the adjuvants Aterbane BR and Silwet L-77 in distilled water, explained by smaller epicuticular wax deposits, as evidenced from leaf surface ultrastructural studies using the scanning electron microscopy technique.

The spray droplet spreading improvement provided by adjuvants on the leaf surfaces is attributed to the solution capability of reducing surface tension, thus increasing the contact area of the droplet with leaf epidermis. Adding adjuvants to the spray mix not always results in the anticipated effect, since leaf surface charac-

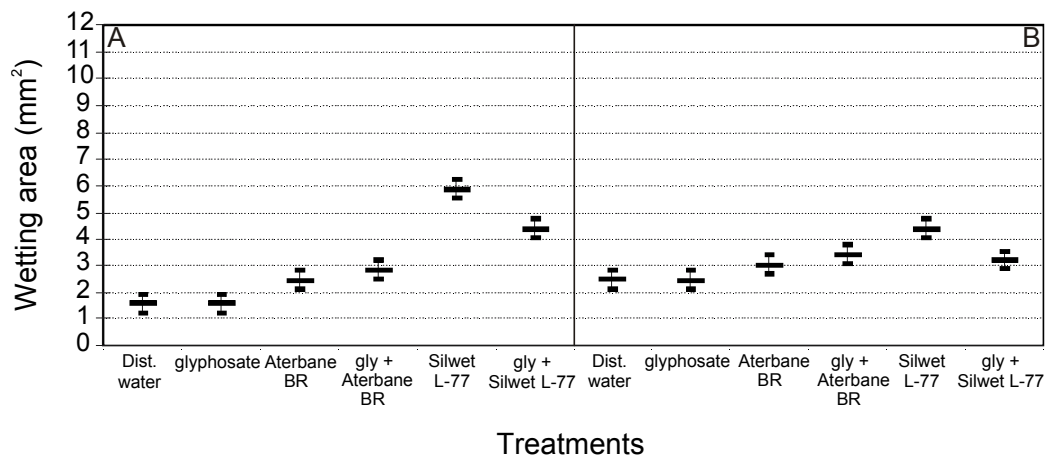

Figure 4 - Wetting area for different solutions provided by a $0.5 \mu \mathrm{L}$ droplet deposited on the adaxial (A) and abaxial (B) surfaces of Heteranthera reniformis leaves (minimum and maximum confidence intervals).

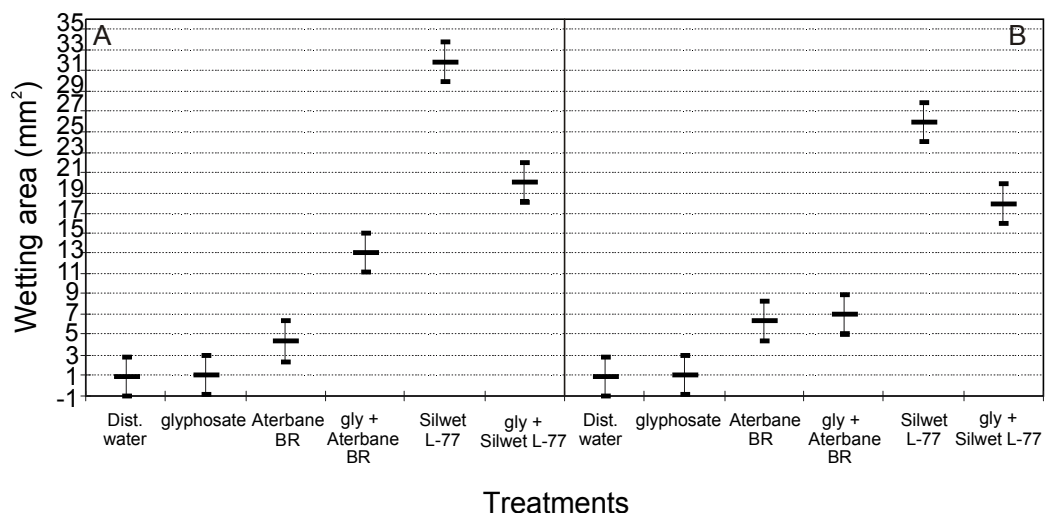

Figure 5 - Wetting area for different solutions provided by a $0.5 \mu \mathrm{L}$ droplet deposited on the adaxial (A) and abaxial (B) surfaces of Typha subulata leaves (minimum and maximum confidence intervals).

Sci. Agric. (Piracicaba, Braz.), v.62, n.3, p.227-234, May/June 2005 
teristics have great influence on spray droplet deposition. In some cases, adjuvants may have an antagonistic effect on the process of absorption of the herbicide by the plant (Field \& Bishop, 1988). Therefore, evaluating the performance of adjuvants under the influence of compounds that constitute herbicides, as well as of the leaf surface, may define the potential of use of these products in postemergence applications for the control of a given weed species that thrives either in a terrestrial or in an aquatic environment.

Figure 6 depicts the wetting area index increase for spray droplets of solutions with different surface tensions in relation to the wetting area of distilled water droplets, on the adaxial and abaxial leaf surfaces of the aquatic weeds studied. The reduction in spray droplet surface tension due to the adjuvants Aterbane BR and Silwet L-77 mixed with glyphosate, had a positive influence by increasing wetting areas on the leaf surfaces of all studied aquatic weed species. An increase in spray droplet spreading on the surfaces of aquatic weed leaves provided by adjuvant Aterbane BR mixed with glyphosate could be detected, in comparison to Aterbane BR individually, revealing a synergistic effect between the products (glyphosate + Aterbane BR), which was more evident for the species Typha subulata. However, adjuvant Silwet L77 mixed with glyphosate resulted in reduced spray droplet spreading on the leaf surfaces of the other aquatic weed species, when compared with the individually-applied Silwet L-77 treatment, providing evidence of an antagonistic effect between the products glyphosate + Silwet L-77. The antagonistic and synergistic effects between products glyphosate + Silwet L-77 and glyphosate + Aterbane $\mathrm{BR}$, respectively, were also observed by

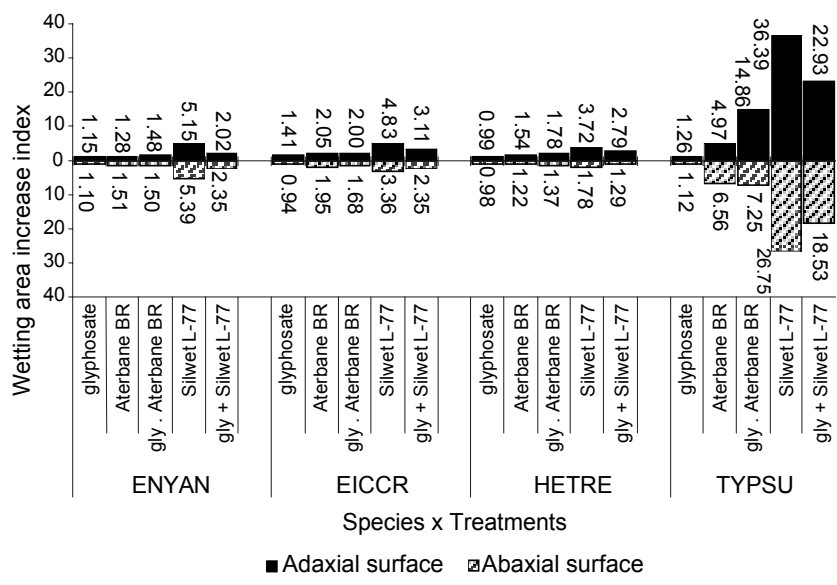

Figure 6 - Increase of the wetting area index for droplets $(0.5 \mu \mathrm{L})$ of solutions with different surface tensions in relation to the wetting area of distilled water droplets (control), on the adaxial and abaxial leaf surfaces of aquatic weeds. ENYAN - Enhydra anagallis, EICCR - Eichhornia crassipes, HETRE - Heteranthera reniformis, and TYPSU - Typha subulata.
Mendonça et al. (1999) in wetting area studies with glyphosate solutions on nutsedge leaves (Cyperus rotundus).

The leaf surfaces of the species Enhydra anagallis, Eichhornia crassipes, and Heteranthera reniformis presented the smallest wetting area increase indices in relation to the other species. However, Typha subulata was the species with the highest wetting area increase indices, with values in the order of $1.26-1.12$; 4.87 - 6.56; 14.86 - 7.25; 36.39 - 26.75; and 22.93 - 18.53, respectively, for the adaxial and abaxial leaf surfaces, for corresponding solutions of Rodeo, Aterbane BR, Rodeo + Aterbane BR, Silwet L-77, and Rodeo + Silwet L-77.

Silva (2003) evaluated spray mix deposition and observed that adjuvant Silwet L-77 $\left(0.01 \% \mathrm{v} \mathrm{v}^{-1}\right)$ applied individually provided the best spray mix distribution uniformity on Typha subulata leaves as compared with a mix containing adjuvant Aterbane BR $\left(0.5 \% \mathrm{v} \mathrm{v}^{-1}\right)$, also applied individually. Evaluating the performance of adjuvants in solutions without the addition of herbicides has little practical use, since the presence of the herbicide may condition different surface tension values in relation to those verified in its absence (Costa, 1997).

In general, spray droplet surface tension of glyphosate solutions mixed with the adjuvants Aterbane BR and Silwet L-77 were below the surface tension that would induce the penetration of the solutions via stomata $\left(32 \mathrm{mN} \mathrm{m}^{-1}\right)$; the spray droplet surface tension reduction due to the adjuvants Aterbane BR and Silwet L-77 mixed with glyphosate had a positive influence by increasing wetting areas of the leaf surfaces of all studied aquatic weed species.

\section{REFERENCES}

BUICK, R.D.; BUCHAN, G.D.; FIELD, R.J. The role of surface tension of spreading droplets in absorption of a herbicide formulation via leaf stomata. Pesticide Science, v.38, p.227-235, 1993.

CARBONARI, C.A.; MARTINS, D.; TERRA, M.A. Controle de Brachiaria subquadripara e Brachiaria mutica através de diferentes herbicidas aplicados em pós-emergência. Planta Daninha, v.21, p.79-84, 2003. Edição especial

CARDOSO, L.R.; MARTINS, D.; KURAMAE, E.E.; TANAKA, R.H.; MORI, E.S. Variabilidade genética de acessos de aguapé coletados no Estado de São Paulo. Planta Daninha, v.20, p.1-6, 2002. Edição Especial.

CARDOSO, L.R.; MARTINS, D.; TERRA, M.A. Sensibilidade a herbicidas de acessos de aguapé coletados em reservatórios de Estados de São Paulo. Planta Daninha, v.21, p.61-67, 2003. Edição especial

CORREAA, T.M.; VELINI, E.D. Desenvolvimento de equipamento para medição da tensão superficial estática de soluções. In: CONGRESSO BRASILEIRO DA CIÊNCIA DAS PLANTAS DANINHAS, 23., Gramado, 2002. Resumos. Gramado: Sociedade Brasileira da Ciências das Plantas Daninhas, 2002. p.686.

COSTA, E.A.D. Efeitos de surfatantes sobre a tensão superficial de soluções de Rodeo. Botucatu: UNESP/FCA, 1997. 73p. (Dissertação - Mestrado).

ESTEVES, F. de A. Fundamentos de limnologia. 2.ed. Rio de Janeiro: Interciência, 1998. 602p.

FIELD, R.J.; BISHOP, N.G. Promotion of stomatal infiltration of glyphosate by an organosilicone surfactant reduces the critical rainfall period. Pesticide Science, v.24, p.55-62, 1988. 
GREENE, D.W.; BUKOVAC, M.J. Stomatal penetration: effect of surfatants and role in foliar absorption. American Journal of Botany, v.61, p.100 106, 1974.

HESS, F.D.; FALK, R.H. Herbicide deposition on leaf surfaces. Weed Science, v.38, p.280-288, 1990.

JOHNSTONE, D.R. Spreading and retention of agricultural sprays on foliage. In: VAN VALKENBURG, W. (Ed.). Pesticide formulations. New York: Marcel Dekker, 1973. 481p.

KIRKWOOD, R.C. Use and mode of action of adjuvants for herbicides: a review of some current work. Pesticide Science, v.38, p.93-102,1993.

MARTINS, D.; VELINI, E.D.; CAVENAGHI, A.L.; MENDONCAA, C.G MENDONÇA, C.G. Controle químico de plantas daninhas aquáticas em condições controladas-caixas d'água. Planta Daninha, v.17, p.289296, 1999.

MATUO, T.; NAKAMURA, S.H.; ALMEIDA, A. Efeitos de alguns adjuvantes da pulverização nas propriedades físicas do líquido. Summa Phytopathologica, v.15, p.163-173, 1989.

MENDONÇA, C.G.; VELINI, E.D.; MARTINS, D.; MENDONÇA, C.G Avaliação da tensão superficial e área de molhamento de soluções de glyphosate com surfatantes em folhas de tiririca. Planta Daninha, v.17, p355-365, 1999.

MENDONÇA, C.G. Algumas características da superfície foliar de diversas plantas daninhas monocotiledôneas. Botucatu: UNESP/FCA, 2000. 89p. (Dissertação - Mestrado).

MONTÓRIO, G.A. Eficiência dos surfatantes de uso agrícola na redução da tensão superficial. Botucatu: UNESP/FCA, 2001. 72p. (Tese Doutorado).
PIMENTEL-GOMES, F. Curso de estatística experimental. 6.ed. Piracicaba: Gráfica Binetti, 1976. 430p.

RODRIGUES, B.N.; ALMEIDA, F.S. Guia de herbicidas. 4.ed. Londrina ANDEF, 1998. 648p

SILVA, J.R.V. Controle químico e deposição da calda de pulverização em dois estágios de desenvolvimento de plantas de Typha subulata Crespo \& Peres-Moreau f. Botucatu: UNESP/FCA, 2003. 74p. (Dissertação Mestrado).

STOCK, D.; HOLLOWAY, P.J. Possible mechanisms for surfactant-induced foliar uptake of agrochemicals. Pesticide Science, v.38, p.165-177, 1993.

TANAKA, R.H.; CARDOSO, L.R.; MARTINS, D.; MARCONDES, D.A.S MUSTAFÁ, A.L. Ocorrência de plantas aquáticas nos reservatórios da Companhia Energética de São Paulo. Planta Daninha, v.20, p.101-111, 2002. Edição especial.

VELINI, E.D.; TRINDADE, M.L.B. Comportamento de herbicidas na planta. Épocas de aplicação de herbicidas. In: SIMPÓSIO NACIONAL SOBRE MANEJO INTEGRADO DE PLANTAS DANINHAS EM HORTALIÇAS, Botucatu, 1992. Anais. Botucatu: UNESP/FCA, 1992. p.65-86.

Received April 16, 2004

Accepted April 14, 2005 